\title{
Isobutylmethylxanthine Fails to Stimulate Chloride Secretion in Cystic Fibrosis Airway Epithelia
}

\author{
Barbara Grubb, Eduardo Lazarowski, Michael Knowles, and Richard Boucher \\ Department of Medicine, University of North Carolina at Chapel Hill, Chapel Hill, North Carolina
}

\begin{abstract}
It has been proposed that a combination of an activated adenylyl cyclase and a high concentration of a phosphodiesterase inhibitor (isobutylmethylxanthine [IBMX], $5 \mathrm{mM}$ ) stimulates $\mathrm{Cl}^{-}$secretion mediated by the heterologously expressed cystic fibrosis transmembrane regulator protein carrying the most common cystic fibrosis (CF) mutation $(\triangle \mathrm{F} 508)$. We tested whether $\mathrm{Cl}^{-}$secretion could be stimulated by this protocol in vitro and in vivo in CF airway epithelia expressing endogenous $\Delta F 508$ CFTR protein. In cultured airway preparations, forskolin (a direct adenylyl cyclase activator) stimulated $\mathrm{Cl}^{-}$secretion in amiloride-pretreated normal $\left(\Delta \mathrm{I}_{\mathrm{sc}}=7.1 \pm 1.7 \mu \mathrm{A} \cdot \mathrm{cm}^{-2}\right)$ but not $\mathrm{CF}$ tissues $\left(\Delta \mathrm{I}_{\mathrm{sc}}=-0.2 \pm 0.1\right.$ $\left.\mu \mathrm{A} \cdot \mathrm{cm}^{-2}\right)$. Unexpectedly, IBMX partially inhibited the forskolin-induced $\mathrm{Cl}^{-}$secretion in normal tissues; IBMX addition had no effect on CF tissues. Direct measurements of cell cAMP concentrations revealed that $0.1 \mathrm{mM}$ IBMX and forskolin produced the maximum levels of cell cAMP levels attainable with this drug combination, and $5 \mathrm{mM}$ IBMX was without further effect. The combination of forskolin $\left(10^{-5} \mathrm{M}\right)$ and isoproterenol, an adenylyl cyclase activator $\left(10^{-5} \mathrm{M}\right)$, produced approximately 3 times higher levels of cAMP than forskolin/IBMX but also did not induce $\mathrm{Cl}^{-}$secretion in $\mathrm{CF}$ tissues. Studies of $\mathrm{Cl}^{-}$secretion in vivo, assessed by the transepithelial electric potential difference (PD), showed that isoproterenol $\left(10^{-5} \mathrm{M}\right)$ stimulated $\mathrm{Cl}^{-}$secretion $(\Delta \mathrm{PD}=-16.3 \pm 4.3 \mathrm{mV} ; n=4)$ in nasal epithelia of normal subjects but not in CF patients homozygous for the $\triangle \mathrm{F} 508$ mutation $(\triangle \mathrm{PD}=-2.6 \pm 1.9 \mathrm{mV}$; $n=5)$. No additive effects of IBMX $(5 \mathrm{mM})$ were observed in either group. We conclude that combinations of adenylyl cyclase activators and IBMX are not effective in initiating $\mathrm{Cl}^{-}$secretion in CF airway epithelia.
\end{abstract}

Cystic fibrosis (CF) is expressed in the lung as a chronic bacterial infection of the airways that leads to diffuse bronchiectasis (1). Although the detailed pathophysiology of CF lung disease is not understood, it is likely that abnormal electrolyte transport is a primary contributor to airways dysfunction in CF. A reduced capacity to secrete $\mathrm{Cl}^{-}$ions toward the airway lumen in response to agents that regulate cell cyclic adenosine monophosphate (cAMP) levels, e.g., $\beta$-agonists (2-4), and hyperabsorption of $\mathrm{Na}^{+}$ions from the airway lumen to the blood compartment $(5-8)$ have both been reported as electrolyte transport abnormalities in CF airways.

Pharmacologic therapies designed to modify abnormal electrolyte transport in the $\mathrm{CF}$ lung may prove beneficial. The $\mathrm{Na}^{+}$channel blocker, amiloride, provides partial pro-

(Received in original form September 2, 1992 and in revised form December 11, 1992)

Address correspondence to: Barbara Grubb, Ph.D., Division of Pulmonary Diseases, Department of Medicine, University of North Carolina at Chapel Hill, Chapel Hill, NC 27599-7020.

Abbreviations: cyclic adenosine monophosphate, cAMP; cystic fibrosis, $\mathrm{CF}$; cystic fibrosis transmembrane regulator, CFTR; collagen matrix supports, CMS; isobutylmethylxanthine, IBMX; short-circuit current, Isc; Eagle's modified essential medium, MEM; potential difference, PD.

Am. J. Respir. Cell Mol. Biol. Vol. 8. pp. 454-460, 1993 tection of the lung from disease-induced decline in airflow obstruction (9). Further therapeutic benefit may be expected from activating the defective $\mathrm{Cl}^{-}$secretory path. Direct pharmacologic studies of this problem have been made possible by the cloning of the CF gene (10). Using recombinant DNA technology, the protein product of this gene, the "cystic fibrosis transmembrane regulator" (CFTR), has been expressed in heterologous cell systems, e.g., Xenopus oocytes (11). Initial reports suggest that CFTR is the cAMP-dependent $\mathrm{Cl}^{-}$channel itself $(12,13)$. In the recent studies of Drumm and colleagues (11), data were obtained indicating that frog oocytes expressing CFTR containing the common phenylalanine deletion CF mutation $\Delta F 508$ could be stimulated to generate a $\mathrm{Cl}^{-}$current when exposed to a combination of a direct activator of adenylyl cyclase (forskolin) and high concentrations $(5 \mathrm{mM})$ of the phosphodiesterase inhibitor isobutylmethylxanthine (IBMX). These researchers speculated that partial $\mathrm{Cl}^{-}$channel function of the mutated CFTR ( $\Delta F 508$ ) could be achieved by a high degree of cAMP-dependent phosphorylation of the CFTR protein.

In the present study, we attempted to induce $\mathrm{Cl}^{-}$secretion in CF airway epithelia by raising intracellular cAMP to high levels using combinations of adenylyl cyclase activators and a high concentration of IBMX. In vitro experiments employing cultured cell preparations and in vivo bioelectric 
measurements of the apical membrane $\mathrm{Cl}^{-}$conductance of airway epithelia were utilized.

\section{Materials and Methods}

\section{Subjects}

For the in vitro studies, nasal or bronchial specimens were obtained from six CF patients during surgery for nasal obstruction or lung transplantation ( 3 males, 3 females; mean age, $20.4 \pm 3.4 \mathrm{yr}$ ). Five CF patients were genotyped, as follows: four were $\Delta F 508 / \Delta F 508$; one $\Delta F 508 /$ unknown. Specimens from normal subjects were obtained from nasal reconstructive surgery (13 men, 4 women; mean age, $43.8 \pm 4.6$ yr). All normal subjects had no family history of CF.

For the in vivo studies, five CF patients, homozygous for the $\Delta$ F508 mutation, were studied ( 3 men, 2 women; mean age, $29.4 \pm 1.6 \mathrm{yr}$ ). Normal subjects for the in vivo electric potential difference (PD) studies were age-matched for the CF subjects ( 1 man; 3 women; mean age, $27.3 \pm 1.3 \mathrm{yr}$ ). All were free of disease, were using no medications, and had no family history of CF. All studies were approved by the University of North Carolina Committee on the Rights of Human Subjects.

\section{Cell Culture}

Cell culture techniques have been previously described (14). In brief, cells were disaggregated from resected airway specimens $\left(4^{\circ} \mathrm{C}, 24\right.$ to $48 \mathrm{~h}$; protease XIV; Sigma Chemical Co., St. Louis, $\mathrm{MO}$ ), concentrated, and plated on collagen matrix supports (CMS), 3.0 or $4.5 \mathrm{~mm}$ in diameter (two to six preparations per patient) for bioelectric studies. TranswellCols (1.2 cm; Costar; Cambridge, MA) were employed in studies of cAMP metabolism. Cells were maintained in F-12 media supplemented with insulin $(10 \mu \mathrm{g} / \mathrm{ml})$, endothelial cell growth substance $(7.5 \mu \mathrm{g} / \mathrm{ml})$, transferrin $(5 \mu \mathrm{g} / \mathrm{ml}), \mathrm{T}_{3}$ $\left(10^{-9} \mathrm{~m}\right)$, and hydrocortisone $\left(5 \times 10^{-9} \mathrm{M}\right)$. After 5 days in culture, the media was supplemented (1:1) with $3 \mathrm{~T} 3$ cell conditioned media (15). Cells plated on the CMS were monitored daily for confluence and development of transepithelial electric PD.

\section{Measurement of cAMP Accumulation}

cAMP accumulation was monitored essentially as described previously $(14,16)$. Briefly, 0.7 and $0.3 \mathrm{ml}$ of Hepes-buffered (20 mM, pH 7.5) Eagle's modified essential medium (MEM) containing 2 to $3 \mu \mathrm{Ci} / \mathrm{ml}$ of $\left[{ }^{3} \mathrm{H}\right]$ adenine were added to the serosal and mucosal side of the epithelial sheets, respectively, and the cells were incubated for $3 \mathrm{~h}$ at $37^{\circ} \mathrm{C}$. The medium was aspirated, the cells were washed twice with Hepes-MEM, and fresh aliquots, same volume as above, of Hepes-MEM containing pertinent drugs were added. The reactions were carried out at $37^{\circ} \mathrm{C}$ and were terminated at the indicated times by aspiration of the medium followed by the immediate bilateral addition of $5 \%$ trichloroacetic acid containing $0.5 \mathrm{mM}$ cAMP. $\left[{ }^{3} \mathrm{H}\right] \mathrm{cAMP}$ was separated from $\left[{ }^{3} \mathrm{H}\right] \mathrm{ATP}$ by sequential passage of the trichloroacetic acid extract over Dowex and alumina columns. Aliquots of the cAMP fractions were assayed spectrophotometrically at 259 $\mathrm{nm}$ to correct for recovery of cAMP. Experiments were carried out with triplicate samples that differed $<10 \%$ from the mean. The results are expressed as the percent of conversion of $\left[{ }^{3} \mathrm{H}\right] \mathrm{ATP}$ to $\left[{ }^{3} \mathrm{H}\right] \mathrm{CAMP}$.

\section{Bioelectric Characterization of $\mathrm{Cl}^{-}$Transport in Cultured Airway Epithelia}

Cell preparations were mounted in Ussing chambers and bathed in a Krebs bicarbonate Ringers solution that was gassed $\left(95 \% \mathrm{O}_{2} / 5 \% \mathrm{CO}_{2}\right)$ and warmed $\left(37^{\circ} \mathrm{C}\right)$. The preparations were voltage-clamped to record the short-circuit current $\left(I_{\mathrm{sc}}\right)$, a measure of active ion transport rates. Transepithelial voltage pulses $( \pm 10 \mathrm{mV})$ were generated intermittently (every $6 \mathrm{~s}$ ) so that transepithelial resistance could be calculated. $I_{s c}$ and the voltage pulses were recorded on a strip chart recorder. After steady-state $\mathbf{I}_{\mathrm{sc}}$ was achieved, drugs were added cumulatively. Amiloride $\left(10^{-4} \mathrm{M}\right)$ was added to the apical bathing solution to convert the tissues from the $\mathrm{Na}^{+}$-absorptive to the $\mathrm{Cl}^{-}$secretory mode (17). Forskolin, at a maximally effective concentration $\left(10^{-5} \mathrm{M}\right)$ as determined in preliminary studies, was added bilaterally and $\mathrm{I}_{\mathrm{sc}}$ was measured for 10 min. Preliminary studies in normal tissues showed that IBMX was equally effective when applied to the apical or basolateral surface, and the effects of exposure of each surface to maximal IBMX concentration were not additive. Because of effects on ATP responses when applied to the apical surface (see below), IBMX was usually applied to the basolateral surface and $\mathrm{I}_{\mathrm{sc}}$ was monitored for an additional $10 \mathrm{~min}$. In some experiments, a combination of isoproterenol $\left(10^{-5} \mathrm{M}\right)$ and forskolin $\left(10^{-5} \mathrm{M}\right)$ was added after amiloride with and without IBMX $(0.1 \mathrm{mM})$ pretreatment. ATP $\left(10^{-4} \mathrm{M}\right)$ was added to the apical surface at the end of each protocol.

\section{In Vivo Transepithelial Electric PD}

The in vivo PD technique previously reported by Knowles and co-workers $(18,19)$ was employed. In brief, the transepithelial PD was measured between a Ringer's-filled exploring bridge (PE 50 tubing) positioned on the nasal mucosa and a reference bridge (Ringer $4 \%$ agar in a 21 -gauge needle) positioned underneath the skin of the forearm. The PD was measured by a voltmeter (University of North Carolina Department of Electronics) and recorded on the strip chart. For delivery of drugs and solutions of different ionic composition, a second bridge (PE 50 tubing) positioned adjacent to the exploring bridge was utilized to perfuse solutions at the site of the PD measurement at the rate of $5 \mathrm{ml} / \mathrm{min}$. The typical protocol involved the following sequential measurements: (I) steady-state PD $(<5 \%$ change over 30 s) during superfusion of either $\mathrm{Cl}^{-}$-free (gluconate replacement) Ringer's or low $\mathrm{Cl}^{-}$, raised $\mathrm{K}^{+}$solution containing amiloride $\left(10^{-4} \mathrm{M}\right)$; (2) addition of the $\beta$-agonist isoproterenol $\left(10^{-5} \mathrm{M}\right)$ and amiloride on the mucosal surface for $3 \mathrm{~min}$; (3) superfusion of IBMX (5 mM), isoproterenol $\left(10^{-5} \mathrm{M}\right)$, and amiloride for $5 \mathrm{~min}$; (4) superfusion of ATP $\left(10^{-4} \mathrm{M}\right)$ plus isoproterenol, IBMX, and amiloride onto the mucosal surface for $2 \mathrm{~min}$.

\section{Solutions and Drugs}

A Krebs Ringer's bicarbonate solution was utilized for in vitro studies of cultured monolayers $(20,21)$. In some in vitro studies, the apical solution of the culture was bathed by solutions containing low $\mathrm{Cl}^{-}\left(3 \mathrm{mM} \mathrm{Cl}-\mathrm{Cl}^{-}\right.$replaced by gluconate), raised $\mathrm{K}^{+}\left(100 \mathrm{mM}\right.$, replacing $\left.\mathrm{Na}^{+}\right)$, and amiloride $\left(10^{-4} \mathrm{M}\right)$. Similar solutions and $\mathrm{Cl}^{-}$-free only (gluconate 
replacement [22]) were utilized for the in vivo experiments, except that $25 \mathrm{mM}$ Hepes was utilized to buffer the $\mathrm{pH}$ of the high $\mathrm{K}^{+}$, low $\mathrm{Cl}^{-}$Ringer's solution because of the inability to keep the solution adequately gassed with $5 \% \mathrm{CO}_{2}$ throughout the perfusion tubing. Forskolin (Sigma) dissolved in a $10^{-2} \mathrm{M}$ stock of ethanol vehicle, isoproterenol (Sigma) dissolved in $10^{-2} \mathrm{M}$ stock in appropriate vehicle, and ATP (Boehringer Mannheim, Indianapolis, IN) dissolved in Ringer's as a $10^{-2} \mathrm{M}$ stock were utilized. IBMX (Sigma) was added to the Ussing chamber as a dry powder, or as a suspension in Ringer's ( $50 \mathrm{mM}$ stock), or after generation of a $200 \mathrm{mM}$ stock solution $(300 \mathrm{mM}$ sucrose, $\mathrm{pH} 8.5$ solution). No differences in bioelectric effects in normal tissues were noted among the different delivery modes. For cAMP studies, IBMX was dissolved in $0.1 \mathrm{~N} \mathrm{NaOH}$ as a 50 $\mathrm{mM}$ stock. Solutions containing the desired final concentration of IBMX were adjusted to $\mathrm{pH} 7.4$ with $\mathrm{HCl}$ before their addition to the tissues.

\section{Statistics}

For the in vitro studies, the maximum change in $\mathbf{I}_{s c}$ induced by an agonist was compared with baseline. Significance of changes was estimated by utilizing paired $t$ tests for group data (4 to 15 per group). To estimate the difference in responses to agonists between $\mathrm{CF}$ and normal preparations, changes induced by agonists for the two groups were compared by unpaired $t$ tests. For the in vivo PD responses, changes induced by agonists at different time points were compared with basal PDs within a group by paired $t$ tests and the changes between the $\mathrm{CF}$ and normal groups compared by unpaired $t$ tests. Unless otherwise stated, all values are mean $\pm S E M$, with the number of tissues shown in parentheses.

\section{Results}

Figure 1 shows tracings of the responses of normal and CF cell culture preparations, pretreated with amiloride to generate $\mathrm{Cl}^{-}$secretion, to the sequential addition of forskolin $\left(10^{-5} \mathrm{M}\right)$ and IBMX $(5 \mathrm{mM})$. In response to forskolin, the normal tissue shows an increase in the $\mathrm{I}_{\mathrm{sc}}$, an index of $\mathrm{Cl}^{-}$ secretion, followed by inhibition of $I_{\mathrm{sc}}$ in response to addition of IBMX. The CF tissue exhibits a smaller residual $\mathbf{I}_{\mathrm{sC}}$ after amiloride, consistent with the defective basal $\mathrm{Cl}^{-}$conductance that limits the capacity to generate a $\mathrm{Cl}^{-}$secretory current $(2-4,23)$. Neither forskolin alone nor forskolin combined with IBMX induces a $\mathrm{Cl}^{-}$secretory current in the CF preparation. The mean data for a series of tissues exposed to these maneuvers are shown in Figure 2A. Forskolin routinely induces an increase in $\mathrm{Cl}^{-}$secretion in normal tissues followed by a modest inhibition of the forskolinstimulated $\mathrm{Cl}^{-}$current with the subsequent addition of IBMX. In contrast, CF tissues respond neither to forskolin nor to the combination of forskolin and IBMX.

We used ion substitution maneuvers to increase the sensitivity of the in vitro system to small effects of the IBMX on the $\mathrm{Cl}^{-}$secretory path (Figure 2B). In these studies, the apical side was bathed with low $\mathrm{Cl}^{-}$, raised $\mathrm{K}^{+}$amiloride $\left(10^{-4} \mathrm{M}\right)$-containing solutions to generate a much larger electrochemical driving force selectively favoring $\mathrm{Cl}^{-}$secretion than occurs after amiloride treatment alone $(17,24)$.
A

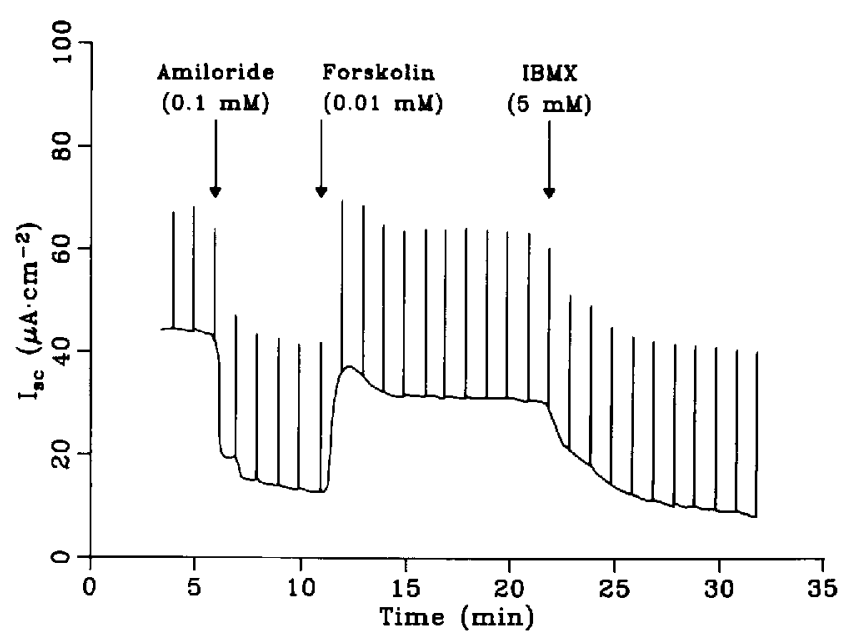

B

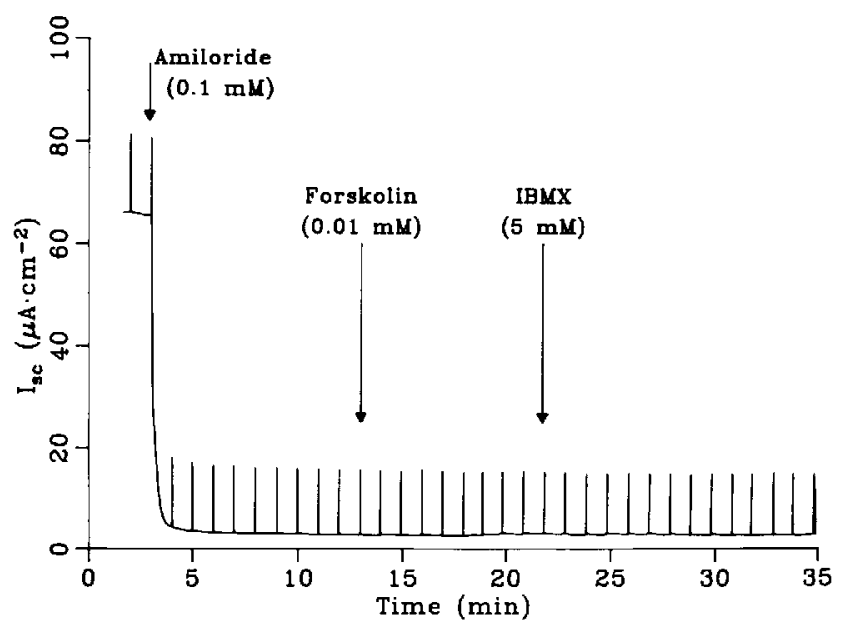

Figure 1. $\mathrm{Cl}^{-}$secretory responses $\left(\mathrm{I}_{\mathrm{sc}}\right)$ of amiloride $\left(10^{-4} \mathrm{M}\right)$ pretreated cultured normal (A) and CF (B) airway epithelial preparations to cumulative addition of forskolin $\left(10^{-5} \mathrm{M}\right)$ and IBMX (5 mM).

Under these conditions, forskolin induced a large increase in $\mathrm{I}_{\mathrm{sc}}$ in normal tissues, whereas an inhibition of this current was observed with addition of $5 \mathrm{mM}$ IBMX (Figure 2B). There was no effect of forskolin or IBMX (5 mM) in forskolin-pretreated tissues under these conditions in $\mathrm{CF}$ tissues.

Because $\mathrm{CF}$ tissues failed to secrete $\mathrm{Cl}^{-}$ions in response to forskolin and IBMX, we tested the response of $\mathrm{CF}$ preparations to a $\mathrm{Cl}^{-}$secretagogue of a different class, ATP (25). In preliminary studies, we noted that the presence of $5 \mathrm{mM}$ IBMX bilaterally in the bathing solutions resulted in a smaller response to mucosal ATP than typically observed in normal or CF airway epithelia. In both normal $(n=9)$ and CF $(n=5)$ tissues, the response to apical ATP was blunted in the presence of apical IBMX $\left(\Delta \mathrm{I}_{\mathrm{sc}}=14.4 \pm 2.1\right.$ $\mu \mathrm{A} \cdot \mathrm{cm}^{-2}$, normal; $\left.\Delta \mathrm{I}_{\mathrm{sc}} 19.7 \pm 8.9 \mu \mathrm{A} \cdot \mathrm{cm}^{-2}, \mathrm{CF}\right)$ as com pared with basolateral IBMX $\left(\Delta \mathrm{I}_{\mathrm{sc}}=28.4 \pm 5.9 \mu \mathrm{A} \cdot \mathrm{cm}^{-2}\right.$, normal; $\left.\Delta \mathrm{I}_{\mathrm{sc}}=29.1 \pm 8.6 \mu \mathrm{A} \cdot \mathrm{cm}^{-2}, \mathrm{CF} ; P<0.05\right)$. Thus, it appears that IBMX may be a relatively weak antagonist for 

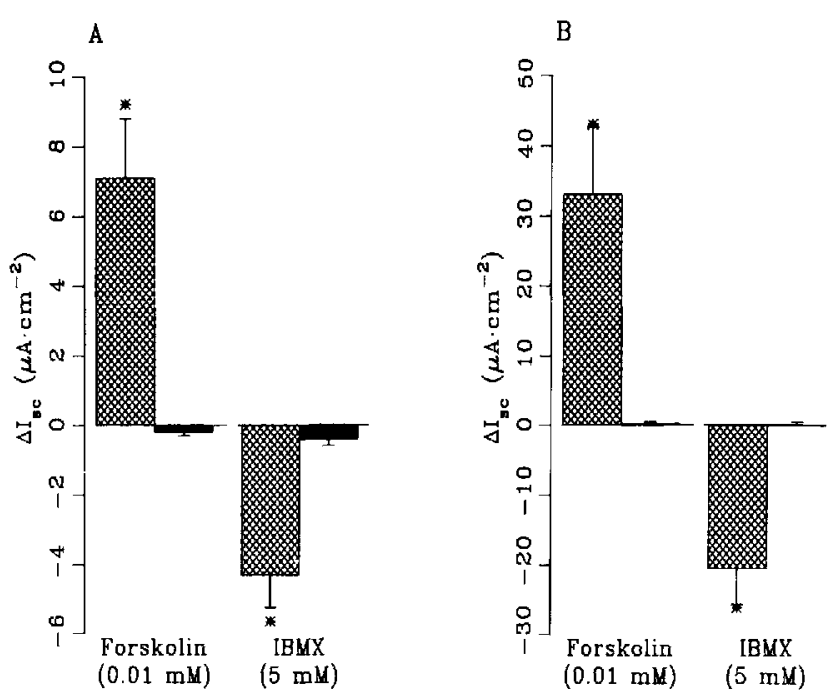

Figure 2. Mean $\mathrm{Cl}^{-}$secretory response $\left(\Delta \mathrm{I}_{\mathrm{SC}}\right)$ of amiloride $\left(10^{-4}\right.$ $\mathrm{M})$-pretreated cultured normal (hatched bars) and CF (solid bars) airway epithelial preparations to cumulative addition of forskolin $\left(10^{-5} \mathrm{M}\right)$ and IBMX (5 mM) in Ringer's solutions (A) or reduced luminal $\mathrm{Cl}^{-}$solutions (B). Note change in scale of ordinate in panels $A$ and $B$.

the apical membrane $P_{2}$ receptor previously reported on these cells $(25,26)$. Importantly, the CF and normal cells both respond to ATP with $\mathrm{Cl}^{-}$secretion, indicating that the lack of response to forskolin/IBMX in CF epithelia is not due to unresponsive tissues.

Because IBMX failed to increase the rate of $\mathrm{Cl}^{-}$secretion of forskolin-treated normal and CF tissues (Figure 2), we tested whether IBMX in the range of concentrations employed was capable of maximizing the cellular cAMP levels in combination with forskolin. Results of the concentrationeffect relationship between added concentrations of IBMXand forskolin-stimulated cellular cAMP accumulation in epithelial cultures are shown in Figure 3. Forskolin induced an approximately 3 -fold increase over basal cAMP levels. The addition of IBMX further raises the intracellular cAMP level, with a maximal effective concentration of $0.1 \mathrm{mM}$. No added effects are seen with $5 \mathrm{mM}$ as compared with $0.1 \mathrm{mM}$. No differences were detected between $\mathrm{CF}$ and normal preparations.

We explored further the observation that IBMX inhibited $I_{s c}$ after forskolin treatment in normal tissues. The inhibitory effect of IBMX on $I_{s c}$ was similar when IBMX was delivered unilaterally on the basolateral or apical surface. The absolute magnitude of the inhibition of $I_{s c}$ was directly proportional ( $r=0.79, P<0.01 ; n=11)$ to the magnitude of the stimulation of $\mathrm{I}_{\mathrm{sc}}$ by forskolin. The dose dependence of the inhibition was further investigated in forskolin-pretreated preparations that were sequentially exposed to $0.1 \mathrm{mM}$ followed by $5 \mathrm{mM}$ IBMX in the apical or basolateral solution. The forskolin-induced current $\left(\Delta \mathrm{I}_{\mathrm{sc}}=12.5 \pm 2.4\right.$ $\mu \mathrm{A} \cdot \mathrm{cm}^{-2}$ ) was not changed by the addition of $0.1 \mathrm{mM}$ IBMX $\left(0.5 \pm 0.2 \mu \mathrm{A} \cdot \mathrm{cm}^{-2}\right)$, whereas the subsequent addition of $5 \mathrm{mM}$ IBMX inhibited the current by $2.2 \pm 0.5$ $\mu \mathrm{A} \cdot \mathrm{cm}^{-2}(n=5)$.

We performed two additional maneuvers in an attempt to

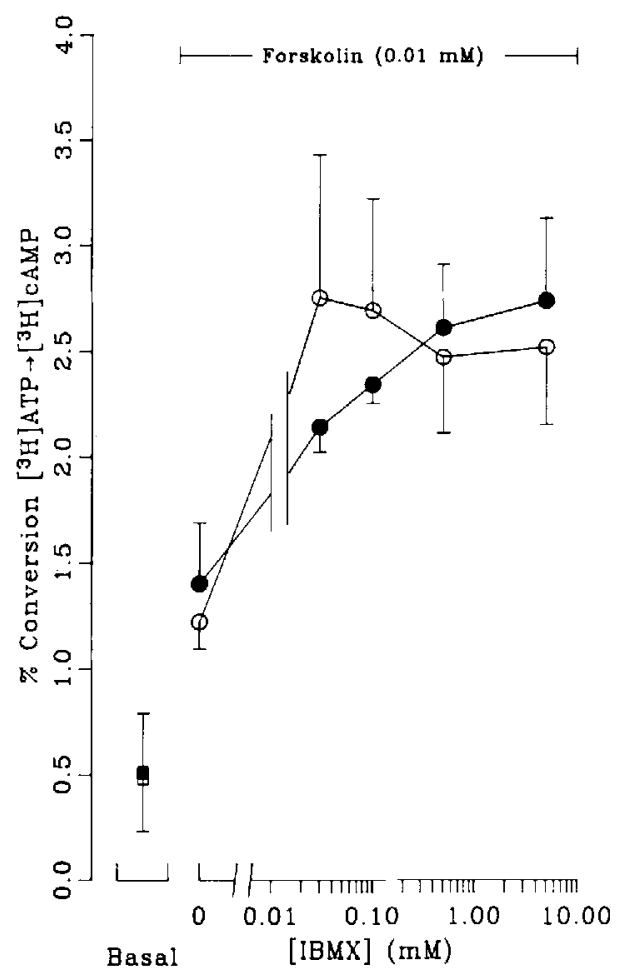

Figure 3. Effect of IBMX on forskolin-stimulated cAMP accumulation in human nasal epithelium. Cells from normal subjects (solid symbols) or CF patients (open symbols) were preincubated for 10 min with vehicle (basal) and with forskolin $\left(10^{-5} \mathrm{M}\right)$ alone or forskolin with the indicated concentration of IBMX. Squares denote basal cAMP levels for normal subjects (solid square) and CF patients (open square). Circles denote values obtained during forskolin treatment (see upper brackets) for normal subjects (solid circles) and CF patients (open circles). The results were plotted as the percent conversion of $\left[{ }^{3} \mathrm{H}\right] \mathrm{cAMP}$ and are the mean of triplicate determinations from four individuals.

stimulate $\mathrm{Cl}^{-}$secretion in CF tissues in vitro. First, we took advantage of synergism of forskolin and isoproterenol to generate very high levels of intracellular cAMP (14). A1though the combination of isoproterenol $\left(10^{-5} \mathrm{M}\right)$ and forskolin $\left(10^{-5} \mathrm{M}\right)$ was 3 -fold more effective $(36.7 \pm 1.0 \%$ conversion of ATP to cAMP) in raising cell cAMP levels than forskolin $\left(10^{-5} \mathrm{M}\right)$ plus $0.1 \mathrm{mM}$ IBMX $(12.7 \pm 3.4 \%$ conversion of ATP to CAMP), this combination did not induce $\mathrm{Cl}^{-}$secretion in $\mathrm{CF}$ tissues $\left(\Delta \mathrm{I}_{\mathrm{sc}}=0.1 \pm 0.5\right.$ $\mu \mathrm{A} \cdot \mathrm{cm}^{-2}, n=5$ ) and was no more effective in inducing $\mathrm{Cl}^{-}$secretion in normal tissues than forskolin alone $\left(\Delta \mathrm{I}_{\mathrm{SC}}\right.$ $=11.2 \pm 1.2 \mu \mathrm{A} \cdot \mathrm{cm}^{-2}, n=3$ ). Second, we attempted to increase sensitivity by inhibiting possible dephosphorylation of CFTR using okadaic acid, a phosphatase inhibitor (27). Preliminary experiments suggested that $10^{-6} \mathrm{M}$ okadaic acid was the maximal concentration that could be delivered without tissue damage. Pretreatment of normal tissues with okadaic acid $\left(10^{-6} \mathrm{M}\right)$ did not increase sensitivity to forskolin $\left(\Delta \mathrm{I}_{\mathrm{sc}}=10.2 \pm 2.1 \mu \mathrm{A} \cdot \mathrm{cm}^{-2}\right.$ and $14.6 \pm 1.78 \mu \mathrm{A} \cdot \mathrm{cm}^{-2}$ without and with okadaic acid, respectively; $n=3$ each) nor did it unmask responses to forskolin and IBMX in CF tissues $\left(\Delta \mathrm{I}_{\mathrm{sc}}=0.1 \pm 0.8 \mu \mathrm{A} \cdot \mathrm{cm}^{-2}, n=4\right)$. Similar findings were observed with another phosphatase inhibitor, calyculin A (28). 


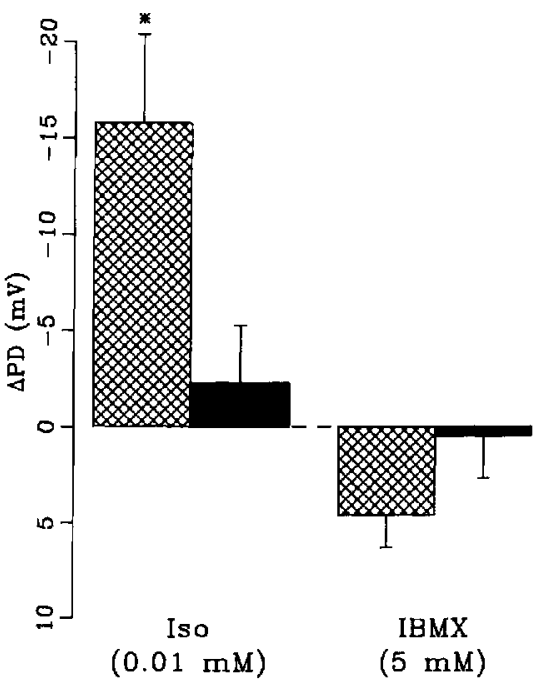

Figure 4. The change in nasal PD in vivo in normal subjects (hatched bars) and CF patients (solid bars) in response to cumulative addition of isoproterenol $\left(10^{-5} \mathrm{M}\right)$ and IBMX $(5 \mathrm{mM})$ during superfusion with nominally $\mathrm{Cl}^{-}$-free solutions containing amiloride $\left(10^{-4} \mathrm{M}\right)$.

Finally, we tested whether IBMX could initiate $\mathrm{Cl}$ secretion in vivo. The nasal lumen was superfused with $\mathrm{Cl}^{-}$free solutions containing amiloride to maximize sensitivity of the technique to small changes in apical membrane $\mathrm{Cl}$ conductance (22). Analysis of the steady-state responses revealed that isoproterenol induced a sustained $(3 \mathrm{~min})$ increase in PD in normal subjects and addition of IBMX had no further effect (Figure 4). In contrast, in CF patients no sustained responses were observed to isoproterenol or IBMX during up to $6 \mathrm{~min}$ of superfusion. ATP was effective in raising $\mathrm{PD}$ in both normal subjects $(\triangle \mathrm{PD}=11.3 \pm 3.2 \mathrm{mV}$, $n=3)$ and $C F$ patients $(\triangle \mathrm{PD}=14.1 \pm 2.1 \mathrm{mV}, n=3)$, but the responses of both subject groups in the presence of $5 \mathrm{mM}$ IBMX were smaller than previously reported (29).

\section{Discussion}

These studies demonstrate that high concentrations of IBMX $(5 \mathrm{mM})$ combined with direct activation of adenylyl cyclase (forskolin) in vitro or a receptor-mediated adenylyl cyclase activator (isoproterenol) in vivo failed to stimulate $\mathrm{Cl}^{-}$ secretion in $\mathrm{CF}$ airway epithelia. The large $\mathrm{Cl}^{-}$secretory responses of CF tissues to ATP, a $\mathrm{Cl}^{-}$secretagogue of another class $(25,26)$, indicate that the tissues were capable of $\mathrm{Cl}^{-}$secretion. The forskolin- or $\beta$-agonist-stimulated $\mathrm{Cl}^{-}$ secretory rates in normal tissues were not increased by IBMX.

Because forskolin, $\beta$-agonists, and IBMX modulate $\mathrm{Cl}$ secretory rates by a signal transduction system that involves cAMP, the relationships between these agents and cell cAMP levels were examined. Three key points emerged. First, based on the observation that forskolin alone is maximally effective in initiating $\mathrm{Cl}^{-}$secretion (Figure 2), it appears that a 3-fold increase in cell cAMP levels (Figure 3) is sufficient to activate fully the cAMP-dependent pathway that regulates $\mathrm{Cl}^{-}$secretion in human airway epithelia (30). This relationship is typical of other reports in which modest increases in cell cAMP levels were sufficient to activate fully cAMP-dependent effector pathways (31). Second, it appears that $0.1 \mathrm{mM}$ IBMX in forskolin-pretreated normal and $\mathrm{CF}$ tissues generates the maximal concentration of cellular cAMP possible by this combination of reagents in human airway epithelial cells (Figure 3). Thus, the failure of the $\mathrm{CF}$ cells to respond to the combination of forskolin and IBMX (up to $5 \mathrm{mM}$ ) does not reflect a failure of these agents to achieve the maximal cellular cAMP concentrations possible with this drug combination. Third, the drug combination of isoproterenol and forskolin, operating synergistically on adenylyl cyclase (14), generates approximately 3 -fold higher levels of cAMP than forskolin/IBMX but did not increase the magnitude of $\mathrm{Cl}^{-}$secretory rates in normal tissues or induce $\mathrm{Cl}^{-}$secretion in $\mathrm{CF}$ tissues. Thus, achieving cell cAMP levels substantially higher than possible with the combination of forskolin/IBMX does not activate $\mathrm{Cl}^{-}$ secretion in $\mathrm{CF}$ airway epithelia.

High concentrations of IBMX ( $5 \mathrm{mM})$ had unexpected effects on human airway epithelia. First, high concentrations of IBMX may block the $\mathrm{Cl}^{-}$secretory path. Inhibition of $I_{\mathrm{sc}}$ in normal but not CF tissues is consistent with an inhibitory action of IBMX on the $\mathrm{Cl}^{-}$secretory path. Because there is no difference in cellular cAMP levels in response to 0.1 and $5 \mathrm{mM}$ of IBMX, this inhibitory effect likely is a nonspecific effect of IBMX. Second, IBMX at high concentrations $(5 \mathrm{mM})$ appears to have weak antagonist effects on the purinergic receptor that transduces the ATP-induced $\mathrm{Cl}^{-}$current.

The reasons for the discrepancy between the data presented here and those of Drumm and colleagues (11) are not clear but can be analyzed conceptually in several ways. The first analysis focuses on the cellular metabolism of $\Delta \mathrm{F} 508$ CFTR and whether $\triangle F 508$ CFTR maintains partial $\mathrm{Cl}^{-}$ transport function. Recently, it has been suggested that the mutated CFTR ( $\triangle$ F508) is recognized as abnormal and catabolized intracellularly before the insertion into the plasma membrane site required for $\mathrm{Cl}^{-}$transport (32). It is conceivable that the overexpression of $\triangle F 508$ CFTR and/or perhaps inefficient intracellular catabolism of a foreign protein in frog oocytes permits partially functional (33) $\Delta F 508$ CFTR protein to be inserted in the oocyte membrane, where it is available for induction of cAMP-dependent $\mathrm{Cl}^{-}$transport. The failure of forskolin and IBMX to stimulate endogenous $\Delta$ F508-mediated transport in airway epithelia could reflect the relatively low level of endogenous production of CFTR by airway epithelia (34) and/or efficient intracellular catabolism of $\triangle \mathrm{F} 508$ CFTR in airway epithelia, resulting in little or no $\triangle F 508$ CFTR in the plasma membrane for cAMPdependent $\mathrm{Cl}^{-}$transport. A second possible explanation for the difference between our results and those of Drumm and colleagues (11) relates to the temperature at which the cells were cultured. It has been shown that 3T3 fibroblasts transfected with $\triangle F 508 \mathrm{CFTR}$ and maintained at $37^{\circ} \mathrm{C}$ failed to express a cAMP-mediated $\mathrm{Cl}^{-}$conductance, whereas when these cells were maintained at $26^{\circ} \mathrm{C}$, cAMP agonists induced a $\mathrm{Cl}^{-}$conductance in them (35). Our airway epithelia were cultured at $37^{\circ} \mathrm{C}$, whereas frog oocytes, which were em- 
ployed in the study by Drumm and colleagues (11), are usually maintained at $26^{\circ} \mathrm{C}$. The third possible difference between our study and that of Drumm's group (11) focuses on the level of phosphorylation of CFTR and its activity. It is conceivable that the degree of phosphorylation of CFTR is critical for activation of $\mathrm{Cl}^{-}$transport (11), and that the $\triangle$ F508 CFTR endogenously expressed in airway epithelia cannot be phosphorylated to the same extent as the $\Delta \mathrm{F} 508$ CFTR that is expressed in the frog oocyte system. The observation that $\mathrm{Cl}^{-}$secretion in normal cells is maximally stimulated at less than maximal levels of cell cAMP indicates that the cellular phosphorylating activity (cAMP-dependent protein kinase) required for activation of $\mathrm{Cl}^{-}$secretion in airway epithelia is fully maximized by forskolin alone. No comparative cellular cAMP data are available in the oocyte system. It is also conceivable that the phosphorylation of $\triangle$ F508 CFTR is lower in airway epithelia than in the oocyte because of relatively greater dephosphorylation (phosphatase) activity in airway epithelia. Although it is not yet known which cellular phosphatases are active on CFTR, treatment of airway epithelia with known permanent phosphatase inhibitors did not unmask effects of cAMP elevation on $\mathrm{Cl}^{-}$secretion in $\mathrm{CF}$ airway epithelia.

In summary, the combination of activators of adenylyl cyclase and high concentrations of the phosphodiesterase inhibitor, IBMX, did not initiate $\mathrm{Cl}^{-}$secretion in $\mathrm{CF}$ airway epithelia in vitro or in vivo. Thus, treatment of CF patients with high concentrations of methylxanthines, including theophylline, with the goal of inducing $\mathrm{Cl}^{-}$secretion does not appear warranted. Indeed, IBMX at very high concentrations may have nonspecific effects, e.g., a block of $\mathrm{Cl}^{-}$conductance and inhibition of $\mathrm{P}_{2}$ receptors. In addition, it has been shown that agents that raise cell cAMP in CF airways may further increase the abnormally high basal rate of $\mathrm{Na}^{+}$ transport (6). Thus, the development of $\mathrm{Cl}^{-}$secretagogues in $\mathrm{CF}$ airway epithelia that focus on elevating the levels of cell cAMP concentrations may be unproductive, and strategies focusing on alternative pathways, such as purinoceptors, may be preferable.

Acknowledgments: The writers wish to thank Dr. Francis Collins for useful discussions, Nathalie Mayenge and Joe Robinson for technical assistance, and Ms. Aluoch Ooro for editorial assistance. This research was supported by National Institutes of Health Grants (HL-34332 and RR-000046) and Grant R025 from the Cystic Fibrosis Foundation.

\section{References}

1. Wood, R. E., T. F. Boat, and C. F. Doershuk. 1976. Cystic fibrosis. Am. Rev. Respir. Dis. 113:833-878.

2. Welsh, M. J., and C. M. Liedtke. 1986. Chloride and potassium channels in cystic fibrosis airway epithelia. Nature 322:467-470.

3. Boucher, R. C., E. H. C. Cheng, A. M. Paradiso, M. J. Stutts, M. R. Knowles, and H. S. Earp. 1989. Chloride secretory response of cystic fibrosis human airway epithelia: preservation of calcium but not protein kinase C- and A-dependent mechanisms. J. Clin. Invest. 84:1424-1431.

4. Schoumacher, R. A., R. L. Shoemaker, D. R. Halm, E. A. Tallant, R. W. Wallace, and R. A. Frizzell. 1987. Phosphorylation fails to activate chloride channels from cystic fibrosis airway cells. Nature 330:752-754

5. Boucher, R. C., and E. H. Larsen. 1988. Comparison of ion transport by cultured secretory and absorptive canine airway epithelia. Am. J. Physiol. 254:C535-C547.

6. Boucher, R. C., M. J. Stutts, M. R. Knowles, L. Cantley, and J. T. Gatzy. 1986. $\mathrm{Na}^{+}$transport in cystic fibrosis respiratory epithelia. Abnormal basal rate and response to adenylate cyclase activation. J. Clin. Invest. 78:1245-1252.
7. Willumsen, N. J., and R. C. Boucher. 1991. Sodium transport and intracellular sodium activity in cultured human nasal epithelium. Am. J. Physiol. 261:C319-C331.

8. Willumsen, N. J., and R. C. Boucher. 1991. Transcellular sodium transport in cultured cystic fibrosis human nasal epithelium. Am. J. Physiol. 261:C332-C341.

9. Knowles, M. R., N. L. Church, W. E. Waltner, J. R. Yankaskas, P. H Gilligan, M. King, L. J. Edwards, R. W. Helms, and R. C. Boucher. 1990. A pilot study of aerosolized amiloride for the treatment of cystic fibrosis lung disease. N. Engl. J. Med. 322:1189-1194.

10. Riordan, J. R., J. M. Rommens, B.-T. Kerem, N. Alon, R. Rozmahel, Z. Grzelczak, J. Zielenski, S. Lok, N. Plavsic, J.-L. Chou, M. L. Drumm, M. C. Iannuzzi, F. S. Collins, and L.-C. Tsui. 1989. Identification of the cystic fibrosis gene: cloning and characterization of complementary DNA. Science 245:1066-1073.

11. Drumm, M. L., D. J. Wilkinson, L. S. Smith, R. T. Worrell, T. V. Strong, R. A. Frizzell, D. C. Dawson, and F. S. Collins. 1991. Chloride conductance expressed by delta F508 and other mutant CFTRs in Xenopus oocytes. Science 254:1797-1799.

12. Anderson, M. P., R. J. Gregory, S. Thompson, D. W. Souza, S. Paul, R. C. Mulligan, A. E. Smith, and M. J. Welsh. 1991. Demonstration that CFTR is a chloride channel by alteration of its anion selectivity. Science 253:202-204

13. Bear, C. E., C. Li, N. Kartner, R. J. Bridges, T. J. Jensen, M. Ramjeesingh, and J. R. Riordan. 1992. Purification and functional reconstitution of the cystic fibrosis transmembrane conductance regulator (CFTR). Cell 68:809-818.

14. Lazarowski, E. R., S. J. Mason, L. L. Clarke, T. K. Harden, and R. C. Boucher. 1992. Adenosine receptors on human airway epithelia and their relationship to chloride secretion. Br. J. Pharmacol. 106:774-782.

15. Wu, R, J. Yankaskas, E. Cheng, M. R. Knowles, and R. Boucher. 1985. Growth and differentiation of human nasal epithelial cells in culture. Serum-free, hormone-supplemented medium and proteoglycan synthesis. Am. Rev. Respir. Dis. 132:311-320.

16. Hughes, A. R, and T. K. Harden. 1986. Adenosine and muscarinic cholinergic receptors attenuate cyclic AMP accumulation by different mechanisms in $1321 \mathrm{~N} 1$ astrocytoma cells. Mol. Pharmacol. 237: 173-178.

17. Willumsen, N. J., C. W. Davis, and R. C. Boucher. 1989. Intracellular $\mathrm{Cl}^{-}$activity and cellular $\mathrm{Cl}^{-}$pathways in cultured human airway epithelium. Am. J. Physiol. 256:C1033-C1044

18. Knowles, M. R., J. Gatzy, and R. Boucher. 1981. Increased bioelectric potential difference across respiratory epithelia in cystic fibrosis. $N$. Engl. J. Med. 305:1489-1495.

19. Knowles, M. R., W. H. Buntin, P. A. Bromberg, J. T. Gatzy, and R. C Boucher. 1982. Measurements of transepithelial electric potential differences in the trachea and bronchi of human subjects in vivo. Am. Rev. Respir. Dis. 126:108-112.

20. Boucher, R. C., M. J. Stutts, and J. T. Gatzy. 1981. Regional differences in bioelectric properties and ion flow in excised canine airways. J. Appl. Physiol. 51:706-714.

21. Boucher, R. C., M. J. Stutts, P. A. Bromberg, and J. T. Gatzy. 1981. Regional differences in airway surface liquid composition. J. Appl. Physiol. 50:613-620.

22. Knowles, M., J. Gatzy, and R. Boucher. 1983. Relative ion permeability of normal and cystic fibrosis nasal epithelium. J. Clin. Invest. 71:14101417 .

23. Willumsen, N. J., C. W. Davis, and R. C. Boucher. 1989. Cellular $\mathrm{Cl}^{-}$ transport in cultured cystic fibrosis airway epithelium. Am. J. Physiol. 256:C1045-C1053.

24. Clarke, L. L., A. M. Paradiso, S. J. Mason, and R. C. Boucher. 1992. Effects of bradykinin on $\mathrm{Na}^{+}$and $\mathrm{Cl}^{-}$transport in human nasal epithelium. Am. J. Physiol. 262:C644-C655.

25. Mason, S. J., A. M. Paradiso, and R. C. Boucher. 1991. Regulation of transepithelial ion transport and intracellular calcium by extracellular adenosine triphosphate in human normal and cystic fibrosis airway epithelium. Br. J. Pharmacol. 103:1649-1656.

26. Brown, H. A., E. R. Lazarowski, R. C. Boucher, and T. K. Harden. 1991 Evidence that UTP and ATP regulate phospholipase $C$ through a common extracellular 5'-nucleotide receptor in human airway epithelial cells. $\mathbf{M o l}$. Pharmacol. 40:648-655.

27. Suganuma, M., H. Fujiki, H. Furuya-Suguri, S. Yoshizawa, S. Yasumoto, Y. Kato, N. Fusetani, and T. Sugimura. 1990. Calyculin A, an inhibitor of protein phosphatases, a potent tumor promoter on CD-1 mouse skin. Cancer Res. 50:3521-3525.

28. Lang, R. J., I. Z. Ozolins, and R. J. Paul. 1991. Effects of okadaic acid and ATP $\gamma \mathrm{S}$ on cell length and $\mathrm{Ca}^{2+}$-channel currents recorded in single smooth muscle cells of the guinea-pig taenia caeci. Br. J. Pharmacol. 104:331-336.

29. Knowles, M. R., L. L. Clarke, and R. C. Boucher. 1991. Activation by extracellular nucleotides of chloride secretion in the airway epithelia of patients with cystic fibrosis. N. Engl. J. Med. 325:533-538. 
30. Barthelson, R., and J. Widdicombe. 1987. Cyclic adenosine monophosphate-dependent kinases in cystic fibrosis tracheal epithelium. J. Clin. Invest. 80:1799-1802.

31. Halbrugge, M., C. Friedrich, P. Eligenthaler, P. Schanzenbacher, and U. Walter. 1990. Stoichiometric and reversible phosphorylation of a $46 \mathrm{kDa}$ protein in human platelets in response to CGMP- and cAMP-elevating vasodilators. J. Biol. Chem. 265:3088-3093.

32. Cheng, S. H., R. J. Gregory, J. Marshall, S. Paul, D. W. Souza, G. A. White, C. O'Riordan, and A. E. Smith. 1990. Defective intracellular transport and processing of CFTR is the molecular basis of most cystic fibrosis. Cell 63:827-834.

33. Dalemans, W., P. Barbry, G. Champigny, S. Jallat, K. Dott, D. Dreyer,
R. G. Crystal, A. Pavirani, J. P. Lecocq, and M. Lazdunski. 1991. Altered chloride ion channel kinetics associated with the delta F508 cystic fibrosis mutation. Nature 354:526-528.

34. Sarkadi, B., D. D. Bauzon, W. Huckle, H. S. Earp, A. Berry, H. Suchindran, E. Price, J. Olsen, R. C. Boucher, and G. A. Scarborough. 1992. Biochemical characterization of the CFTR in normal and cystic fibrosis epithelial cells. J. Biol. Chem. 267:2087-2095.

35. Denning, G. M., M. P. Anderson, J. F. Amara, J. Marshall, A. E. Smith, and M. J. Welsh. 1992. Processing of mutant cystic fibrosis transmembrane conductance regulator is temperature-sensitive. Nature 358:761764. 